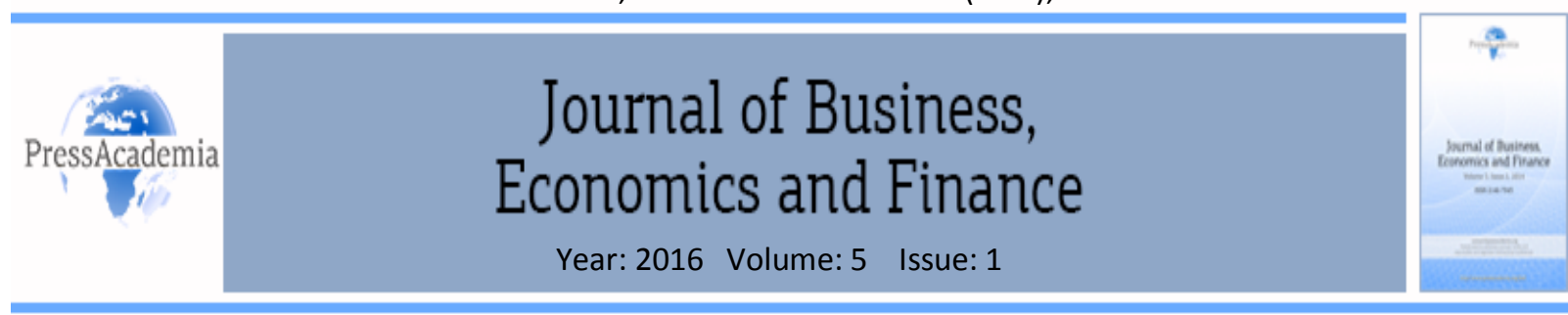

\title{
A STUDY ON ECO-INNOVATION AND ITS DETERMINANTS
}

\section{DOI: 10.17261/Pressacademia.2016116658}

\author{
Billur Engin Balin ${ }^{1}$, H. Dilara Mumcu Akan ${ }^{2}$ \\ ${ }^{1}$ Istanbul University. b.engin@istanbul.edu.tr \\ ${ }^{2}$ Istanbul University. dimumcu@istanbul.edu.tr
}

\begin{abstract}
Environmental problems and the solutions investigated within the economic theory has been high on the global agenda since 70s. Variables that encourage firms to innovate and/or use environment-friendly technologies is an important subtitle in this issue. According to the common definition in the environmental economics literature, eco-innovation consists of new or modified processes, techniques, systems and products to avoid or reduce environmental damage. Although there are a lot of variables that determine the eco-innovation level of a firm, national and international environmental policy -as one of them- worths significantly noting. Under some conditions, the stringency of environmental regulations induces firms to reduce their costs by innovating new environment-friendly technologies. Therefore, environmental regulations may lead a so-called "win-win" situation characterized by both cost reducing/profit maximizing behaviour of the firm and environmental benefits. On the other hand, international harmonization of environmental regulations may create a comperative advantage for the eco-innovationg firms in the newly innovated technologies and strengthen this "win-win" situation. Market structure, technological capabilities, awareness and pressures of the demanders for cleaner technology are the other variables which determine the eco-innovation level of a firm. This study has concentrated on the variables that determine eco-innovation level of a firm. Both endogenous and exogenous variables are analysed in detail. As a consequence, it has been found that (1) the effect of environmental regulations on eco-innovation should be emphasized diligently, (2) international harmonization of environmental regulations supports eco-innovation, and finally (3) increasing awareness of society about environmental issues may be influent on ecoinnovation.
\end{abstract}

Keywords : Environmental Innovation, Eco-innovation, Environmental Policy, Porter Hypothesis, European Union. JEL Classification : Q55, Q58, R11

\section{INTRODUCTION}

Environmental problems and their solutions being taken into consideration in the framework of economic theory from the 1970's onward has been in the upper echelons of the global agenda. The inducement of firms developing and utilizing eco-friendly technologies are one of the important captions within this scope. When literature is being surveyed, it is seen that eco-innovation most specially has been examined by evolutionary economists. Evolutionary economics can be evaluated as a complement of neo-classical environmental economics and ecological economics putting emphasis on eco-innovation (Faber and Frenken, 2009).

According to the prevalent definition "eco-innovations are all measures of relevant actors which; (i) develop new ideas, behaviour, products and processes, apply or introduce them and ii) which contribute to a reduction of environmental burdens or to ecologically specified sustainability targets." (Rennings, 2000:322) A great deal of eco-innovation combines the environmental and firms utilities. In this sense innovations other than different domains are different in terms that eco-innovation, (i) as it is in all kinds of innovations with the spillover effect creates a positive externality, and (ii) reduces environmental externality costs which is a negative externality. 
Depending on the double externality problem, the firms doing eco-innovation are face to face with the problem of creating public goods at a certain extent and this reduces their desire to make eco-innovation. Thereby as long as eco harmful effects are not being punished or environmental contributions are not being remunareted it can be foreseen to lack behind an eco-innovation level which can be considered socially optimum. Eventually likewise it is mentioned about many variables influential in a firm realizing eco-innovation levels among them national and international environmental policies have a special place. It is put forward, under certain assumptions, tightening environmental regulations will encourage the firms to take cost minimizing measures and for this reason urge them to eco innovation. From this point of view environmental policy on one hand would reduce the environmental devastation on the other hand would induce firms to make innovation and create a "win-win" situation by causing them to produce at lower costs and more profitable levels. Conversely the international harmonization of environmental policies would provide a comparative advantage to firms for the new eco-friendly technologies they have developed thus aforementioned "win-win" situation would be stiffened in international markets. Apart from that market structure, the capital stock and technological structure of the firm for the firms to make eco-friendly production the pressures of non-governmental organizations or the demanders of the products pressures can be sighted among the variables determining the eco-innovation level.

\section{THE DETERMINANTS OF ECO-INNOVATION}

In a general sense the determinants of innovation and its subtitle eco-innovation do not submit significant differences. When literature concerning the subject is looked upon it is seen that two factors that influence innovation activity are: on the supply side (technology) and on the demand side (fully informed customer). The supply side factors that are backed up with technological innovations in the primary phase of developing a product and demand factors in the spillover phase of the product will be more effective. (Horbach, 2008) When we look through specific to eco-innovation the costs caused by environmental problems (not being private costs) being external costs means without environmental regulations existing there is no other way to induce firms produce eco-friendly products. Thereby to state economic innovation is the extended form of innovation theory with environmental policy and institutional factors will not be incorrect. In this section the factors determining eco-innovation will be examined adhering to the general innovation theory.

\subsection{Determinants Concerning Supply and Demand Side}

When a firm makes a decision on innovation investment certainly takes two aspects into consideration: the cost and yield of investment to be made. Though detection of the cost of the investment to be made is relatively easy the calculation of the return provided by innovation is more difficult. Likewise, we can mention the innovation made can supply cost saving for the firm and in social sense it will create a positive externality. Particularly the positive externality mentioned for eco-innovation investments are more dominant. (Jaffe et al., 2002). As long as there is no incentive/penalty mechanism the firms will produce without taking into consideration the external benefits they have made, it can be expected that the eco-innovation level socially would be below optimum level. Hence the government coming into sight can fix the market distortions via taking measures for inducing innovation.

When viewed from the supply side, another factor influencing innovation investments is the firm's stock capacity. The holdings of capital stock of a firm both physically and in terms of information capital are the most important factors determining a firm's innovative capacity; for the firms to develop the new goods and production processes. Both research and development and human capital investments (in other words the investment firm makes for his employees) promote such kind of capital stock to be formed. Each product or production process found will increase the firm's capital stock hereafter will induce more innovation to be made. Baumol summarizes this situation with just one sentence: "innovation breeds innovation". (Baumol, 2002:284)

The market structure of the operating firm is also influential on innovation. Nevertheless, we should state that there is no consensus about the direction of the effect. Schumpeterian economists assert a firm having monopoly power, by reason of having the excess profit has the required to reserve for innovation investments, the ability to combine risks, no fear of being forged because of having no rival and can benefit more from 
economies of scale created by innovation; are more inclined to make innovation. (Scherer, 1967; Biglaiser and Horowitz, 1995). In other respects the firm having monopoly power can be seen as a factor causing the firm making innovation an "unnecessary" aspect yet the firm having no other rival might not carry the fear of "being better off". On the contrary a firm operating in a competitive market to increase its market share should always be "better off". This can be seen as a factor inducing innovation. (Geroski, 1990; Oates et al., 1993; Jaffe and Palmer, 1997). When examined from demand side a firm's willingness to make eco-innovation will be associated in a positive way with the demand for the goods produced via this innovation. At this point the public awareness concerning eco-friendly products, the environmental consciousness of consumers and firms, their preferences and intimacy with the subject becomes crucial. In interdisciplinary studies concerning consumption behaviour, the reasons consumers preferring to use eco-friendly or "green" products recently has progressively being examined. (See Mainieri et. al, 1997; Gatersleben et al., 2002; Young et al., 2010).

\subsection{The Environmental Policy's Effect on Eco-Innovation}

\subsubsection{Porter Hypothesis}

Whether the change being done in environmental policies would encourage the firms to make innovations are studied in environmental economics literature generally on the basis of Porter hypothesis. Porter and Van der Linde (1995) in their studies have put forward that tightening of environmental policies would on one side reduce pollution and induce innovation on the other would increase profitability of the firm and create a winwin situation. Figure 1 represents this situation.

Figure 1- The win-win situation environmental policy would create

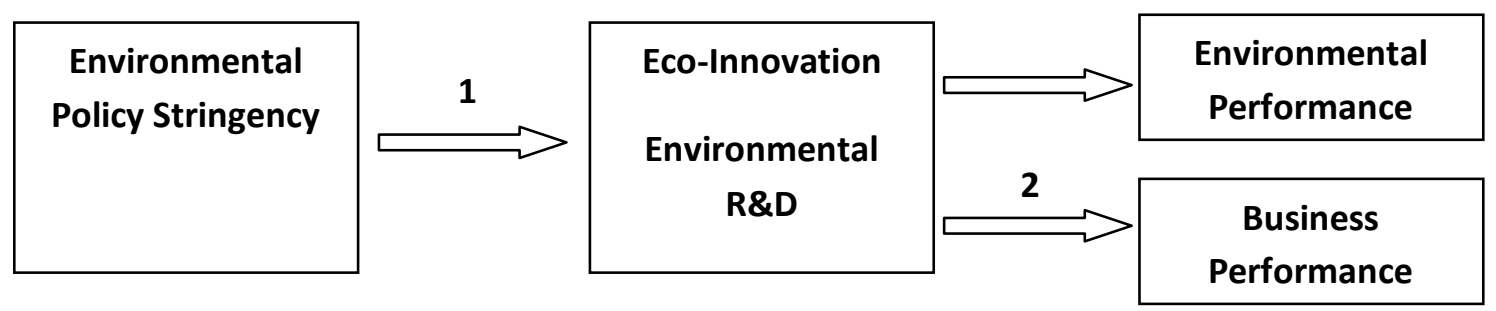

Source: Lanoie, Paul, et al. (2011), "Environmental policy, innovation and performance: new insights on the Porter hypothesis", p. 809

Hereby the point that has to be urged upon is the necessity of inducing eco-innovation with environmental policy. For a firm that operates under perfect competition rules, although cost minimizing measures are taken automatically without having need of any incentive, firms under imperfect competition rules due to imperfect data and coordination problems may not calculate how much saving would environmental innovation investments generate. However, for instance, for a firm that is producing by air polluting; a tax being levied on the unit $\mathrm{CO} 2$ emitted, would be a monetary indicator of reducing emission therefore cost-saving. Eventually the tightening of environmental policy by endogenizing external costs makes the firms to realize cost saving effects binding from eco-innovation.

A secondary component of Porter Hypothesis is the firms operating under the application of environmental policy's have the advantage of acting early and the comparative advantage would enhance the firm's acquired national competitiveness both in national and international markets hereafter cause an increase in profitability. Definitely an eco-innovation made by a firm to register an international effect is only possible if similar environmental policies are practiced in other countries. In this regard, we should notice that as well as the harmonization of environmental policies having effects to both international competitiveness and ecoinnovation. (Beise and Rennings, 2004).

In fact, in the 'optimist' remark of Porter and Van der Linde (1995) it is stated that the tight environmental policies would induce firms to use their substantial resources more efficiently and this would increase the domestic firm's potential to make innovation. Therefore, although other countries do not apply similar arrangements with the comparative advantage based on resource efficiency (increase in competitiveness) it is 
asserted that firms will turn out to be profitable. Here the logic is the efficient use of natural resources are because of them being a partially private good. Since firms have to pay for the water they use in planning and wastes. For this reason natural resource efficiency has been evaluated as a part of total efficiency and the firm's competitiveness.

\subsubsection{Empirical Studies}

Porter hypothesis which explained the relationship between eco-innovation and environmental policy simply and clearly has been subject to many empirical studies. These studies are classified as "weak version" and "strong version" of Porter hypothesis. (Lanoie and others, 2007). The weak version of the hypothesis, examines whether to tighten environmental policy increases innovation or not. This kind of studies test in Figure 1 - flow 1. The strong version of the hypothesis questions whether the tightened environmental policy (via ecoinnovation) provides cost saving to firms. We can think this kind of studies where in Figure 1 - flow 1 together with flow 2 can be tested.

The first study trying to test Porter hypothesis belongs to Jaffe and Palmer (1997). In the study manufacturing industry panel data variables of USA between the years of 1973-1991 were used. Jaffe and Palmer, as an indicator of eco-innovation show research and development investments and successful patent applications. As an indicator of tightening the environmental policy they have used the government's control of pollution spending. According to the conclusion of the studies, though there is no connection among pollution control spendings and successful patent applications, but there is a weak and positive relationship with research and development investments (Elasticity: $+0,15$ ). Accordingly, we can say this study validates the weak version of Porter Hypothesis. Solely a criticism can be made to the study concerning research and development investments which are used as a dependent variable and all of the patent applications (whether related to the environment or not) have been taken into consideration.

Brunnermeir and Cohen (2003), in their study between the years (1983-1992) have used panel data concerning the manufacturing sector in the USA. In this study as an indicator for eco-innovation they have indicated the successful number of "environmental" patent applications and as an indicator of tightening environmental policy they have used the government's pollution control expenditures with public auditing activities. By the results of the studies it is stated that the change in the government's control expenditures over environmental innovation is positive but has a very low level of influence. (Other conditions being constant when pollution control expenditures are increased by 1 million\$ there will be a 0,04 \% increase in environmental patents). Brunnermeir and Cohen attributes the reason of the relationship to be so weak to the restriction on the environmental patterns for manufacturing sector only. No empirical relation has been found among public auditing and patents.

De Vries and Withagen (2005), in their studies, depending on the variables for 14 countries (USA, Germany, United Kingdom, France, Finland, Austria, Denmark, Sweden, Canada, Holland, Poland, Italy, Luxemburg, Switzerland) between the years 1970-2000 have used patents related with environment as an indicator of ecoinnovation. The tightening of the environmental policy has been measured by three indicators: some international environmental treaties to be signed, for different polluters environmental consciousness performance indices and the tightening environment policy taken as a dummy variable. In the conclusion part of the study there is a positive relationship just between dummy variable thirdly stated and eco-innovation level.

Lanoine and others (2007) according to their studies based on variables of OECD study made in 2003 for seven countries (USA, Canada, France, Germany, Hungary, Japan and Norway) have found outcomes validating both the weak and strong versions of Porter Hypothesis. This study's conclusion supporting strong side of Porter Hypothesis is important in terms of determining environmental policy.

Horbach (2007) with the extensive study he did on German panel data variables for the years, 2001 and 2004 has concluded; (i) technological capacity to be improved with research and development has significant effects on eco-innovation, (ii) in the past generally and in environmental sense innovative firms currently still are so. Hence this result confirms Baumol's "innovation breeds innovation" (iii) the increase in expected demand in the future will trigger eco-innovation (iv) environmental administrative tools, general organizational changes 
and developments have importance in inducing eco-innovation. This conclusion is confirming the weak version of Porter Hypothesis.

In another group of studies testing Porter hypothesis, it has been emphasized whichtype of environmental policies will match with the hypothesis. In the aforesaid studies there is a presupposition that the hypothesis is not suitable for all market types and environmental policies. Downing and White (1986) with Millman and Prince (1989) have asserted that market based environmental policy tools have higher augmentative power of research and development investments in respect of product process to control tools, Montenero (2002) states the aforementioned study is valid under perfect competition rules, in imperfect competition markets the arrangements done in terms of environmental standards compared to other instruments are more efficient inducing research and development expenses. Firms under imperfect conditions behave strategically and as a natural consequence of this market based instruments loose their importance.

\section{ECO-INNOVATION IN EUROPEAN UNION}

Within this section we try to examine the weak version of the Porter hypothesis by comparing environmental policy measures with the eco-innovation level on the country and time basis. Firstly it is crucial to touch upon the report of the European Comission on "Attitudes of European entrepreneurs towards eco-innovation" (2011). The report based on the Flash Eurobarometer survey to investigate the behaviour, attitudes and expectations of entrepreneurs towards the development and uptake of eco-innovation as a response to rising prices of resources and resource scarcity. Within the context of the survey a total of 5,222 managers of small and mediumsized companies were interviewed. Among four main topics of the report, drivers for an accelerated uptake of eco-innovation was related our point of view here. The report states that existing regulations and standards with expected future regulations and imposing new standards are highly effective on the eco-innovation investments.

Figure 2: Drivers that could Accelerate Eco-innovation Uptake and Development: Existing Regulations, Including Standards

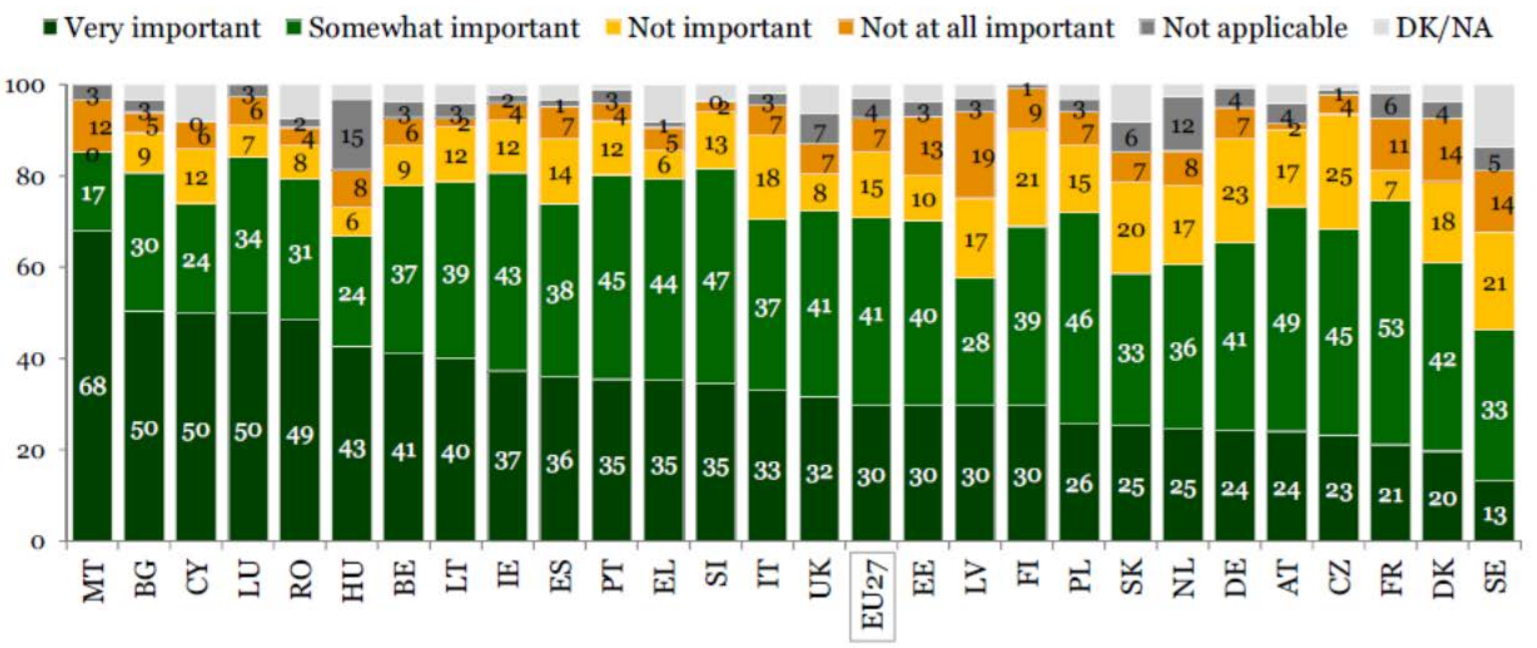

Source: European Commission, "Attitudes of European entrepreneurs towards eco-innovation: Analytical Report", p.47 
Figure 3: Drivers that could Accelerate Eco-innovation Uptake and Development: Expected Future Regulations Imposing New Standards

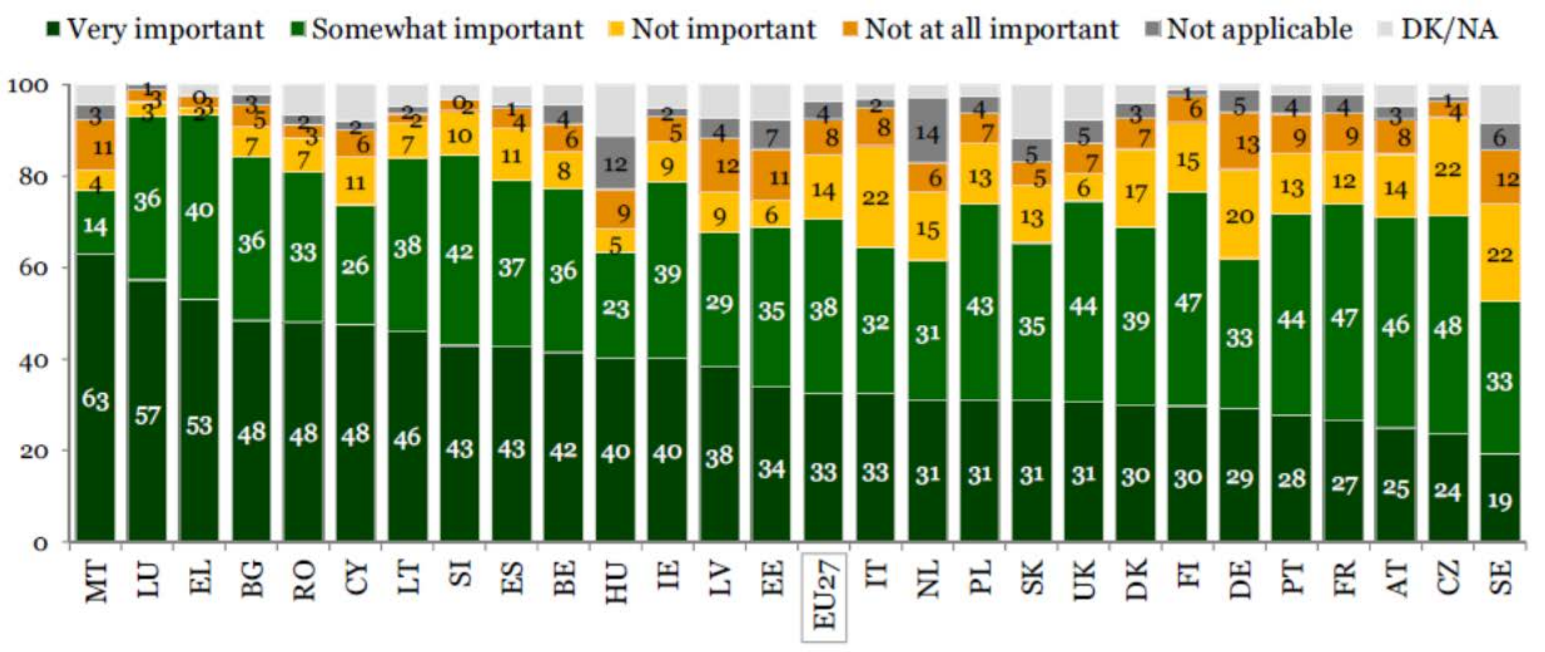

Source: European Commission, "Attitudes of European entrepreneurs towards eco-innovation: Analytical Report”, p.48

As it can be seen from the figures $70 \%$ of the European entrepreneurs found important the environmental regulations for the eco-innovation. However, when we compare these results with eco-innovation index scores of the countries in the same year the expected correlation is not valid for all countries.

Eco-index is calculated by the eco-innovation observatory of the European Commission and it is the first tool to assess and illustrate eco-innovation performance across the EU Member States. The index aims at capturing the different aspects of eco-innovation by applying 16 indicators grouped into five thematic areas: ecoinnovation inputs, eco-innovation activities, eco-innovation outputs, resource efficiency and socio-economic outcomes. Figure 4 represents the eco-index values and survey results about regulations together.

Figure 4: Eco-index Values and Importance of Regulations (2011)

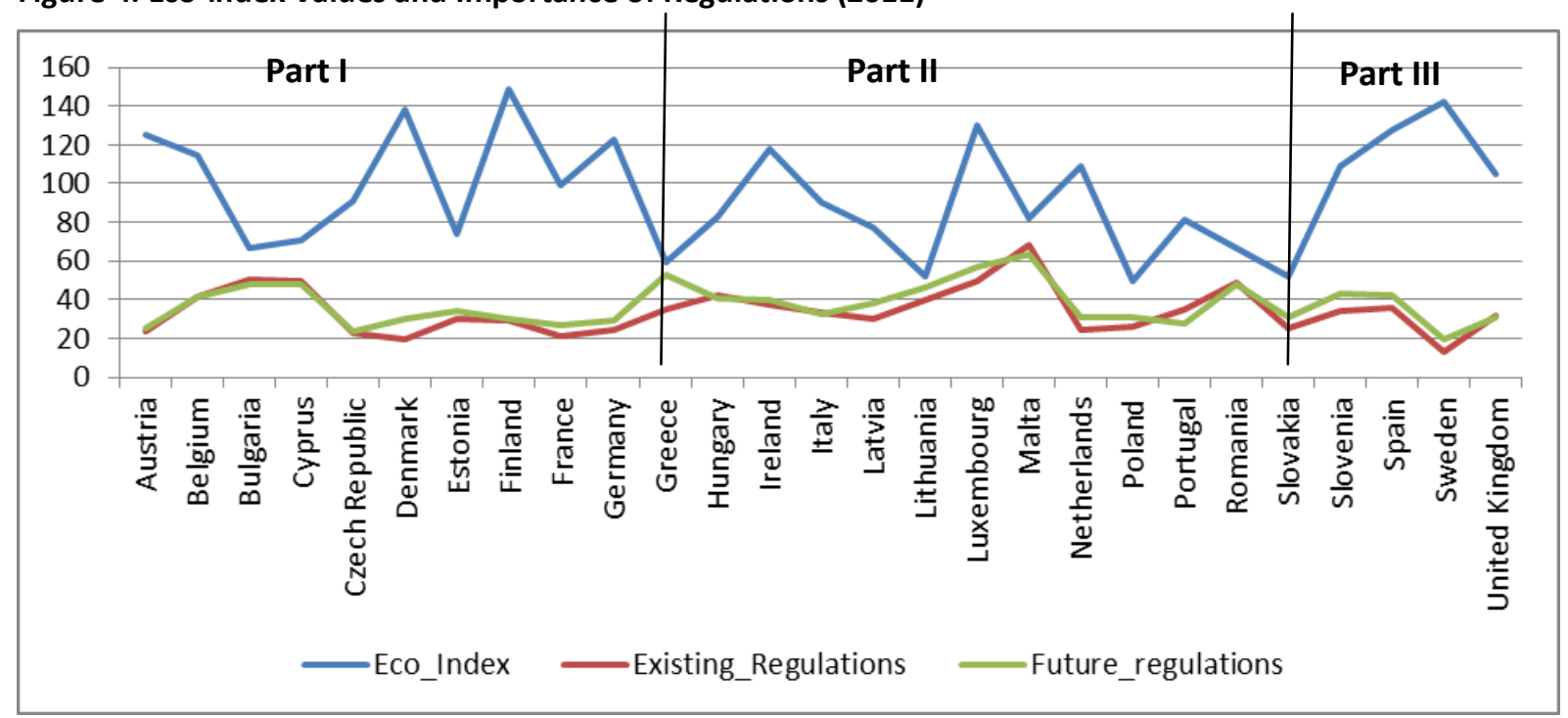

Data Source: Eco-Innovation Observatory Database (http://www.eco-innovation.eu/)

In Figure 4 it can be seen the heterogeneous structure of the countries. For part I and part III we see the negative relationship between the eco-index score and the importance of the regulations stated by the entrepreneurs. However, in part II the expected positive relationship is observed. The reason behind this heterogeneity may be sourced from the difference in current environmental regulation levels of the countries. 
When we analyse the total environmental taxes (as percentage of GDP) and eco-index score, in Figure 5, we see the similar result which supports our point of view.

Figure 5: Eco-index Values and Total Environmental Taxes as \% of GDP (2011)

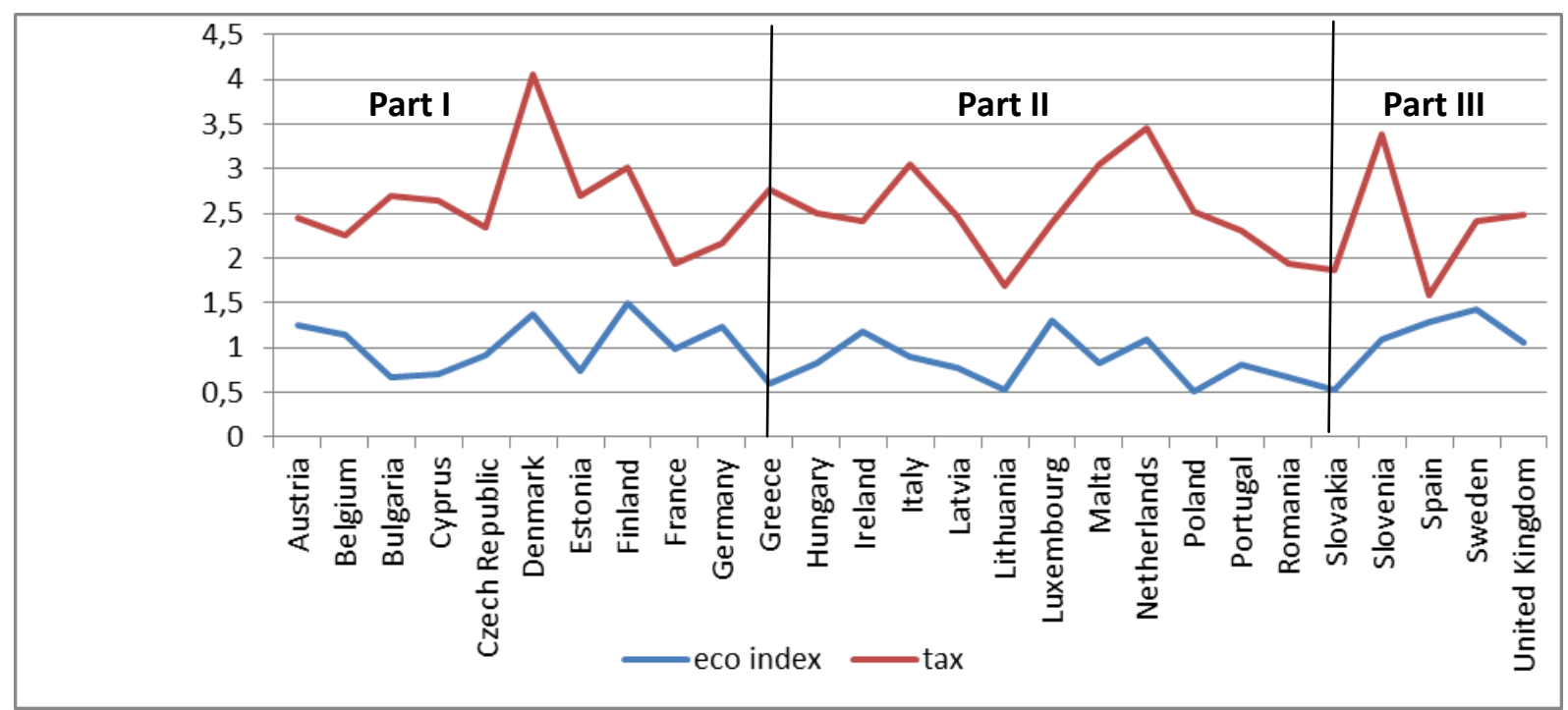

Data Source: Eco-Innovation Observatory Database (http://www.eco-innovation.eu/) and Eurostat (http://ec.europa.eu/eurostat)

\section{CONCLUDING REMARKS}

As a result of increasing industrialization and consumption society how to clean the planet we have polluted or at least how to "optimize" pollution is a topic dealt by various disciplines. The environmental engineers deal with the technical aspects of the topic, the economists by having the consciousness that the source of the question is economics itself, tries to look from the window of economic theory and try to find solution proposals. These proposals can annihilate the results of the question or by focusing on the source of the question aimed at intervention.

In this study by observing what the factors inducing firms to produce eco-friendly products are we have tried to focus on how to intervene for the source of the problem. Among the observed variables we have realized that the environmental policy's effect is in the foreground. Environmental policies applied to minimize or abolish environmental problems creates a two way effect: The pollutant firms are face to face with a new maximization problem taking into consideration environmental policy and they determine their production levels. This situation is the internalization of external cost of polluting the environment. The indirect effect of environmental policy which is also subject to our study, for the firms to get rid of environmental policy liabilities or reduce its effects they have to promote to make eco-innovation.

Likewise as it is held within the scope of our study, the literature survey and empirical studies demonstrate that tightening environmental policy supports eco-innovation partially. In this context, we can say that there is a consensus among firms to avoid increasing compliance costs of environmental policies to tend towards ecofriendly technologies. Conversely the efforts in the subject, whether would increase the firm's performance more clearly. The influence eco-innovation has on the profitability of a firm has to be examined further. 


\section{REFERENCES}

Baumol, W. J., (2002); The Free Market Innovation Machine - Analyzing the Growth Miracle of Capitalism, Princeton University Press, New Jersey.

Beise, M. and Rennings, K., (2004); "Lead Markets and Regulation: A Framework for Analyzing the International Diffusion of Environmental Innovations", Ecological Economics, Volume 52 (1), pp. 5-17.

Biglaiser, G. and Horowitz, J. K., (1995); "Pollution Regulation and Incentives for Pollution-Control Research", Journal of Economics and Management Strategy, Volume 3 (4), pp. 663-684.

Brunnrmeier, S. B. and Cohen M. A. (2003); "Determinants of Environmental Innovation in US Manufacturing Industries", Journal of Environmental Economics and Management, Volume 45, pp. 278-293.

De Vries, F. P. and Withagen, C., (2005); "Innovation and Environmental Stringency: The Case of Sulphur Dioxide Abatement", University of Tilburg Discussion Paper, No: 18, pp. 1- 33.

Downing, P. B. and White, L. J., (1986); “Innovation in Pollution Control”, Journal of Environmental Economics and Management, Volume 8, pp. 225-271.

European Commission, (2011) "Attitudes of European entrepreneurs towards eco-innovation: Analytical Report" (online at http://ec.europa.eu/public opinion/flash/fl 315 en.pdf 07/03/2016)

Faber, A. and Frenken, K., (2009); "Models in Evolutionary Economics and Environmental Policy: Towards an Evolutionary Environmental Economics", Technological Forecasting and Social Change, Volume 76(4), pp. 462-470.

Gatersleben,B. - Steg, L. and Vlek, C., (2002); "Measurement and Determinants of Environmentally Significant Consumer Behavior", Environment and Behavior, Volume 34 (3), pp. 335-362.

Geroski, P.A., (1990); “Innovation, Technological Opportunity, and Market Structure”, Oxford Economic Papers, Volume 42 (3), pp. 586602.

Horbach, J., (2008); "Determinants of Environmental Innovation - New Evidence from German Panel Data Sources", Research Policy, Volume 37, pp. 163-173.

Jaffe, A. and Palmer, K., (1997); "Environmental Regulation and Innovation: A Panel Study", The Review of Economics and Statistics, Volume 10, pp. 610-619.

Jaffe, A. - Newell, R. G. and Stavins, R. N., (2002); "Environmental Policy and Technological Change”, Environmental and Resource Economics, Volume 22 (1-2), pp. 41-69.

Lanoie, P., Laurent-Lucchetti, J., Johnstone, N. and Ambec, S. (2011); “Environmental Policy, Innovation and Performance: New Insights on the Porter Hypothesis", Journal of Economics \& Management Strategy, Volume 20(3), pp. 803-842

Mainieri, T. - Barnett, E. G. - Valdero, T. R. - Unipan, J. B. and Oskamp, S., (1997); “Green Buying: The Influence of Environmental Concern on Consumer Behavior", The Journal of Social Psychology, Volume 137 (2), pp. 189-204.

Milliman, S. R. and Prince, R., (1989); "Firm Incentives to Promote Technological Change in Pollution Control", Journal of Environmental Economics and Management, Volume 17, pp. 247-265.

Montenero, J. P., (2002); “Permits, Standards, and Technology Innovation”, Journal of Environmental Economics and Management, Volume 44, pp. 23-44.

Oates, W. E. - Palmer, K. and Portney, P. R., (1993); "Environmental Regulation and International Competitiveness: Thinking about the Porter Hypothesis", RFF Discussion Paper, 94-02.

Porter, M. E. and van der Linde, C., (1995); "Toward a New Conception of the Environment-Competitiveness Relationship", Journal of Economic Perspectives, Volume 9 (4), pp. 97-118.

Rennings, K., (2000); "Redefining Innovation - Eco-innovation Research and the Contribution from Ecological Economics", Ecological Economics, Volume 32 (2), pp. 319-332.

Scherer, F. M., (1967); “Market Structure and the Employment of Scientists and Engineers”, American Economic Review, Volume 57, pp. 524-531.

Young, W. - Hwang, K. - McDonald, S. ve Oates C. J., (2010); “Sustainable Consumption: Green Consumer Behaviour When Purchasing Products", Sustainable Development, Volume 18, pp. 20-31. 